Research Article

\title{
Political Connections, Debt Restructuring, and Enterprise Investment: Evidence from China
}

\author{
Xinlin $M^{1}$ and Jinglu Jiang $\mathbb{D}^{2,3}$ \\ ${ }^{1}$ School of Economics and Management, China University of Geosciences, Wuhan 430074, China \\ ${ }^{2}$ Institute for Advanced Studies in Finance and Economics, Hubei University of Economics, Wuhan 430205, China \\ ${ }^{3}$ Shanghai Key Laboratory of Financial Information Technology, Shanghai University of Finance and Economics, \\ Shanghai 200433, China \\ Correspondence should be addressed to Jinglu Jiang; jjl_sd@163.com
}

Received 19 February 2020; Accepted 21 May 2020; Published 28 June 2020

Guest Editor: Lifei Chen

Copyright (C) 2020 Xinlin Mo and Jinglu Jiang. This is an open access article distributed under the Creative Commons Attribution License, which permits unrestricted use, distribution, and reproduction in any medium, provided the original work is properly cited.

\begin{abstract}
This paper shows that the link between debt restructuring and enterprise investment in emerging economies hinges critically on the political connections. Taking Chinese A-share listed enterprises from 2005 to 2016 as samples, we examine whether and how political connections affect the relationship between debt restructuring and enterprise investment based on the DID method. The results show that compared with nonpolitically connected enterprises, debt restructuring effectively improves the investment efficiency in enterprises with political ties, which is mainly due to alleviating the overinvestment and underinvestment. Furthermore, the positive effect of debt restructuring on investment is more prominent in enterprises with weak strength of political connection. It is worth noting that as the strength of political connection increases from weak to strong, the positive impact of debt restructuring on investment turns to negative impact, which reflects the heterogeneity of connection strength on the relation between debt restructuring and investment. This paper provides new evidence for understanding the investment behaviour of debt restructuring enterprises and provides some policy implications for managers and decision-makers intending to improve the investment efficiency and enhance the sustainable development of enterprises from the perspective of political connections.
\end{abstract}

\section{Introduction}

As China's economy enters a new normal stage, the downward pressure on economic development is increasing, and enterprise debt defaults occur frequently. Since financially troubled enterprises are unable to meet their obligations in accordance with previous debt contracts, they usually actively coordinate debt renegotiation in order to survive and continue to develop. In other words, debt restructuring is an effective measure for distressed enterprises to alleviate the debt pressure, improve business performance, and then get rid of liquidation or even bankruptcy. Theoretically, debt restructuring is a game between the creditor and debtor. For the debtor, the direct impact of debt restructuring is to mitigate debt crisis and get out of financial difficulties. Debt renegotiation is usually more profitable for creditors than liquidating the debtor enterprise's assets. As a result, enterprises in financial distress often have an incentive to restructure debt privately rather than file for formal bankruptcy.

The relevant literature has conducted theoretical and empirical studies on debt restructuring from the perspectives of restructuring system, bank relationship, earnings management, property right, renegotiation characteristics, investment decisions, and so on [1-4]. However, little attention has been paid to the impact of political connections on the link between debt restructuring and investment in emerging markets. In order to identify the role of political connections on the relation between debt restructuring and enterprise investment, this paper uses DID and PSM methods to find that political connections have a significant impact on the relationship between debt restructuring and enterprise investment based on the samples of Chinese enterprises from 2005 to 2016. China is an ideal research site 
to examine political connections, debt restructuring, and enterprise investment in emerging markets. The reason is that, firstly, as the largest emerging economy, the evidence from China is more helpful in understanding the interaction of political connections, debt restructuring, and enterprise investment in the emerging market. Secondly, the Chinese government often plays an important role in business by taking stakes in companies and appointing senior executives with government backgrounds. The political connections of senior executives in Chinese enterprises provide an opportunity to examine whether and how political connections affect the investment behaviour of debt restructuring enterprises. Finally, debt restructuring is an important way to deleverage. Deleveraging, as one of the important tasks of China's supply-side structural reform, alleviates the debt crisis of distressed enterprises to some extent and increases the driving force for sustainable development. It is of great guiding significance to study the effect of political connections on the link between debt restructuring and enterprise investment under this macro background.

Our findings indicate that the relation between debt restructuring and enterprise investment is significantly influenced by the political connections. Specifically, the debt restructuring effectively alleviates the problem of inefficient investment in politically connected enterprises, which is mainly manifested in observably mitigating overinvestment and underinvestment. Furthermore, the positive effect of debt restructuring on investment is more prominent in enterprises with weak strength of political connection. It is worth noting that as the strength of political connection changes from weak to strong, the positive impact of debt restructuring on investment turns to negative impact, which reflects the heterogeneity of the impact of connection strength on the relation between debt restructuring and investment. To sum up, our research results show that the external governance mechanism tested from the perspective of political connections in China has a crucial impact on the link between debt restructuring and enterprise investment. As far as we know, there is little evidence (theoretically or empirically) about the impact of political connections on the relation between debt restructuring and enterprise investment in emerging market economies. Therefore, this paper aims to fill this gap. This research gap is important because it limits our understanding of the mechanisms that influence the relationship between debt restructuring and investment. Paying attention to the role of political connections will bring the positive effects to the investment decision-making and sustainable development of debt restructuring enterprises.

This study contributes to the literature in the following aspects. First of all, the investigation on the political connections, debt restructuring, and enterprise investment in emerging markets enriches the literature on debt financing and investment. The existing literature on debt restructuring is mainly based on the developed market economy, and little attention has been paid to debt restructuring enterprises in emerging markets. Second, the research of this paper provides new evidence for the relation between debt restructuring and enterprise investment, which is helpful to guide the investment behaviour of debt restructuring enterprises from the perspective of political connections and promote the sustainable development of enterprises. Third, the emerging countries such as China show conspicuous heterogeneity in terms of political connection, and its impact on debt restructuring enterprises has not been paid attention in previous studies. Based on the existing literature, this paper focuses on the impact of political connections on the link between debt restructuring and enterprise investment and holds that political connection is a considerable influencing mechanism to explain the relation between debt restructuring and enterprise investment.

The rest of this paper is organized as follows: Section 2 reviews the existing theoretical and empirical literature and presents our testable research hypotheses. In Section 3, we describe sample and variable measures. Section 4 reports and analyzes the main empirical results. Finally, the conclusions of this paper are presented in Section 5.

\section{Theoretical Analysis and Research Hypothesis}

As we know, enterprises in financial trouble often have an incentive to restructure their debt privately rather than file for formal bankruptcy. Gilson, et al. [5] take American distressed enterprises as a sample and find that enterprises with more intangible assets and more debt owed to bank have a higher probability of debt restructuring, and private renegotiation is more likely to fail when there are more types of outstanding debt. Similarly, Jostarndt and Sautner [6] through the study of German enterprises in distress show that the leverage ratio is higher, the bank debt is more, and the enterprises with higher operating value have a higher probability of debt restructuring. However, enterprises with higher mortgage debt ratio and inadequate financing coordination are more likely to go bankrupt. In addition to studying debt restructuring from the perspective of enterprise's assets and debt characteristics, scholars also pay attention to bank-enterprise relationship, lender type, renegotiation cost, trade credit, and so on. Huang et al. [7] take default enterprises as a research object and find that the bank-enterprise relationship brings strong information advantages to banks in the financial system dominated by banks, which enhances the coordination between banks and reduces information asymmetry as well as debt coordination problems and thus plays restrictive function in costly restructuring applications. Demiroglu and James [8] indicate that bank loans are easier to restructure out of court than loans from institutional lenders. Based on the dynamic model, Nishihara and Shibata [9] theoretically show that lower financing and debt renegotiation costs and cash volatility increase the incentive of shareholders to choose debt restructuring to avoid liquidation. Micucci and Rossi [10] find that in terms of geographical location, the smaller the distance between the bank and debt enterprises, the more the banks rely on soft information instead of credit score (except for credit score used for monitoring), and the higher the probability of debt restructuring. Forgione and Migliardo [11], based on a sample of Italian enterprises, 
show that trade credit, profitability, geographical location, and performance are highly correlated with the possibility of bank debt restructuring of enterprises, and trade credit is widely used by enterprises in financial difficulties.

Several attempts have been made to shed light on the impact of debt restructuring on enterprise decision-making, mainly from the perspectives of management incentives, investment and financing decisions, corporate performance, and earnings management. Debt restructuring is usually a strategy adopted by an enterprise to repay debts and fulfil legal obligations in the contract due to the financial difficulties. Creditors may make concessions in various forms (such as debt relief and debt rollover) in the renegotiation to give debtors opportunity for financial adjustment. Aksu [12] studies the excess returns of distressed enterprises that try to restructure debt privately. The results show that shareholders will receive significant positive announcements and postannouncement excess returns when the enterprise renegotiates. Pawlina [13] establishes a theoretical model to show that debt renegotiation by struggling companies exacerbates underinvestment because the wealth generated by investment is transferred from shareholders to creditors, while underinvestment can be eliminated by giving creditors full bargaining power. Shibata and Nishihara [14] show that the weaker shareholder bargaining power makes the enterprise more likely to be financially constrained and may also lead to a greater tendency to issue renegotiable bonds when the enterprise faces the debt issuance ceiling. Based on the empirical analysis, Sung and Kim [15] believe that debt restructuring (i.e., debt forgiveness) of Korea chaebols after financial crisis helps to improve enterprise performance and achieve the optimal capital structure after the recovery of the national economy.

The convenience and advantages of enterprises with political ties in acquiring capital and information, as well as the dominant position of the banking system, are unique to China [16]. Compared with nonconnected enterprises, enterprises with political connections have inherent advantages in government subsidies and preferential credit, are more likely to obtain financing channels and low-cost funds, and generally face less liquidity constraints. Managers have a strong incentive to overinvest in the case of less liquidity constraints. Furthermore, managers with government working background in politically connected enterprises are often motivated to improve their performance to achieve further promotion, which also increases the overinvestment tendency. In particular, enterprises with strong political connections will naturally expect such "grabbing hand" effect to be stable because strong political ties make it easier for officials to obtain political benefits. Political intervention is a characteristic of China's economy [17]. According to the investment theory, enterprises make investment decisions based on the principle of value maximization and net present value (NPV). However, political intervention will consequentially turn the goals of enterprises into those preferred by the government, such as employment, social stability, and infrastructure, thus distorting the enterprises' investment behaviour and leading to inefficient investment. In the case of strong political connections, enterprises will be subject to strong political interference. However, enterprises subject to strong political intervention are more likely to adopt nonvalue-added strategies for other purposes [18]. In other words, political connection is a double-edged sword with both positive and negative aspects. The debt restructuring in politically connected enterprises provides information for the government to identify the enterprises with poor performance and insolvency, and relevant financial institutions strengthen the supervision and management of restructuring enterprises, so as to mitigate the overinvestment behaviour and play a positive role in enhancing the investment efficiency. Therefore, debt restructuring is conducive to improving the investment efficiency for the politically connected enterprises. However, when the strength of political connection is strong, the negative impact brought by political connection becomes dominant, even exceeding the external supervision and control effect caused by debt restructuring, so that debt restructuring has a negative impact on enterprise investment. Thus, we conjecture that the weak political connection is favorable to the investment of debt restructuring enterprises, but the strong connection will have adverse effect. Therefore, this paper puts forward the research hypothesis: from the perspective of political connections, debt restructuring significantly improves investment behaviour in politically connected enterprises. Compared with enterprises with strong political connection, debt restructuring has a more prominent positive impact on investment in the enterprises with weak political connection.

\section{Empirical Study Design}

3.1. Sample and Data. The samples of this paper include A-share enterprises listed in China from 2005 to 2016. According to previous studies, the samples are further screened to exclude the observation of financial enterprises and key variables with missing data, and all the continuous variables are winsorized at the level of $1 \%$ and $99 \%$. There are 20144 enterprise-year observations in the sample. The data are mainly from the China Stock Market and Accounting Research (CSMAR) database, the annual reports of enterprises listed on the Shanghai Stock Exchange and the Shenzhen Stock Exchange, and the report of marketization index of China's provinces [19], while the data of political connection are collected manually based on the information from CSMAR and annual report disclosure.

3.2. Political Connection Measures. We measure political connection by two indicators. Firstly, the binary variable (GI) is constructed using the personal background information of enterprise executives. Based on the data from CSMAR database and the annual reports of listed enterprises, we manually collect background information for senior management. If the $\mathrm{CEO}$ or chairman of an enterprise is a current or former government official, provincial, or ministerial politician, or military officer, then the enterprise is considered to be politically connected, and GI is equal to 1, otherwise 0 [20-23]. 
Secondly, China is in the stage of economic transformation, the market-oriented reform has not been completed, and the marketization level in different regions shows an extremely unbalanced state. Wang et al. [19] evaluate the marketization process in various regions of China in the past period (2008-2016) and provide a series of marketization indicators. The government-market relationship index (i.e., the government index) is based on the proportion of economic resources allocated by the market, the direct intervention of local government in enterprises, and the government scale. In general, the government index reflects the strength of political connections between local government and enterprises in the market under their jurisdiction [17]. Ceteris paribus, the strength of political connections between local government and enterprises is negatively correlated with the government index, that is, the weaker the political connections, the greater the index value. According to the strength of political connections which is divided into low, middle, and high levels, the binary variable MI1 is set. If an enterprise is headquartered in a region with weak political connections, then the MI1 is equal to 1 , vice versa, the value is 0 (in order to show that the empirical results are not sensitive to the setting of government intervention degree, different from the classification of low, medium, and high political intervention here, we divide the political intervention into low and high levels in the robustness checks (i.e., $50 \%$ in the top and 50\% in the bottom). If the degree of political intervenes is high, MI1 is equal to 1 , otherwise 0 . However, the change in the setting of the degree of political intervention does not affect the main empirical results, which can be seen in Section 4.4).

3.3. Enterprise Investment Measures. This paper evaluates enterprise investment behaviour based on investment expenditure and investment efficiency and further tests the investment efficiency from overinvestment and underinvestment. INV indicates the proportion of new investment expenditure, which is equal to the ratio of capital expenditure to total assets in the current period. Richardson [24] method is adopted to measure the investment efficiency based on the residual term obtained by regression with the new investment in the period as the dependent variable. Although this measure is not perfect, it can use specific enterprise information to measure its investment efficiency. Moreover, it can better avoid the shortcomings of other methods [2]. Therefore, this measurement method has been more and more widely used by scholars [25-27]. In this paper, $A B S I N V$ represents the investment efficiency, which is equal to the absolute value of residual term. The larger the value, the greater the deviation between the actual investment and the expected investment, which means lower investment efficiency. On the contrary, it means that the difference between the actual investment and the expected investment is small or even completely consistent (i.e., the residual term is equal to 0 ), which means higher investment efficiency. If the residual term is greater than 0 , that is, the actual investment is greater than the expected investment, then it means overinvestment and is denoted as EXINV. If the residual term is less than 0, take its absolute value to measure the underinvestment and denote it UNINV. Thus, the higher the value of EXINV and UNINV, the greater the degree of overinvestment and underinvestment.

3.4. Estimation Method. In this paper, the difference-indifferences (DID) model is used to test the impact of political connections on the link between debt restructuring and enterprise investment behaviour. The reason for using the DID model is that in terms of investment, not only debt restructuring enterprises and nondebt restructuring enterprises may be different, but also restructuring enterprises may be different pre and postdebt restructuring. If the two types of enterprises are directly compared without the DID model, it is impossible to rule out whether there is difference in investment before debt restructuring, rather than the restructuring affecting investment. However, if the investment before and after restructuring is directly compared, the investment fluctuation may come from other factors that change over time rather than the effect of debt restructuring. The DID method can control these two differences at the same time, which can eliminate potential interference information more clearly and more reliably identify the impact of debt restructuring on investment under distinct political connections. Furthermore, in order to satisfy the premise hypothesis of the DID method, we adopt the propensity score matching (PSM) method firstly to construct a group of enterprises (the control group) similar in main characteristics for the debt restructuring enterprises (the treatment group) so that the probability of debt restructuring is as similar as possible. Hence, it is assumed that in the case of no debt restructuring, the investment trend of the treatment group is almost the same as that of the control group. DRD is the dummy variable that represents the debt restructuring. If an enterprise restructures the debt, DRD is equal to 1 , vice versa, the value is 0 . TIME is the binary variable of the period ( 0 denotes prerestructuring, and 1 denotes postrestructuring). According to the relevant research, we further control the financial variables, internal governance variables, and enterprise characteristic variables that may have an impact on investment, including leverage ratio (LEV), cash flow (CF), Tobin's Q (Q), equity balance (CSTR), director independence (RID), regulators holdings (ESH), board size (BOARD), listing time (AGE), and enterprise size (SIZE). In addition, we consider year-specific dummy variables to control for country-wide shocks and trends of enterprise investment over time, such as changes in national laws and regulations and economic cycles. We consider industry-specific dummy variables to control for time-invariant and unobserved industrial characteristics that form the investment situation of each industry. As follows, Model (1) is used to test the impact of political connections on the relation between debt restructuring and enterprise investment: 


$$
\begin{aligned}
Y_{i, t}= & \gamma_{0}+\gamma_{1} \mathrm{DRD}_{i, t} \times \mathrm{TIME}_{i, t} \times \mathrm{GI}(\mathrm{MI} 1)_{i, t}+\gamma_{2} \mathrm{DRD}_{i, t} \\
& \times \mathrm{TIME}_{i, t}+\gamma_{3} \mathrm{DRD}_{i, t} \times \mathrm{GI}(\mathrm{MI} 1)_{i, t}+\gamma_{4} \mathrm{TIME}_{i, t} \\
& \times \mathrm{GI}(\mathrm{MI} 1)_{i, t}+\sum \text { Control }+\sum \mathrm{YEAR}+\sum \mathrm{IND}+\varepsilon_{i, t},
\end{aligned}
$$

where $Y$ denotes the enterprise investment, which can be INV, ABSINV, EXINV, and UNINV. GI and MI1 represent proxy variables for political connection. $\gamma_{1}$ is the interaction coefficient we focus on, which reflects the impact of political connections on the relation between debt restructuring and enterprise investment. Table 1 lists the names, notations, and definitions of the primary variables in the paper.

In order to alleviate the problem of selection bias, the PSM method is adopted. The logit model is used to estimate the probability of debt restructuring, which is filtered according to pseudo- $R^{2}$ and AUC values $[2,28]$. Table 2 shows the test results of balance hypothesis of PSM. There is no significant difference of the matched variables between the treatment group and control group after matching. The small standard deviation indicates that the sample matching effect is good. In other words, the balance hypothesis is satisfied. Figure 1 plots the probability density distribution of the treatment group and control group before and after matching. It can be seen that the probability density distribution of two groups's postmatching is similar, which further verifies the validity of sample matching.

\section{Empirical Results and Analysis}

4.1. Descriptive Statistics. Table 3 is the descriptive statistics of the full samples. It can be seen from the investment variables that in nondebt restructuring enterprises (debt restructuring enterprises), the average of INV is 0.039 (0.008), and the average of EXINV is $0.068(0.058)$, indicating that the investment expenditure and overinvestment of nondebt restructuring enterprises are visibly higher than that of debt restructuring enterprises from the mean values. The average of ABSINV is 0.051 (0.049), and the average of UNINV is $0.041(0.045)$, demonstrating that the investment efficiency and underinvestment of debt restructuring enterprises are higher than that of nondebt restructuring enterprises from the mean values. From the perspective of the mean of financial variables, governance variables, and characteristic variables, the leverage ratio (LEV), Tobin's $Q$ (Q), and listing time (AGE) of debt restructuring enterprises are obviously higher than that of nondebt restructuring enterprises. However, the cash flow (CF), enterprise size (SIZE), regulators holdings (ESH), and board size (BOARD) of debt restructuring enterprises are clearly lower than that of nondebt restructuring enterprises. On the whole, it illustrates the apparent characteristics of high debt level and insufficient liquidity of assets in debt restructuring enterprises.

Figure 2 plots the investment of both debt restructuring enterprises and nondebt restructuring enterprises under different strength of political connection. It can be seen that under the situation with strong political connection, the investment expenditure of enterprises as a whole is higher, the investment efficiency of nondebt restructuring enterprise is lower, and the overinvestment is more serious. When the political connection is weak, the investment spending and overinvestment of debt restructuring enterprise are notably lower; however, the underinvestment is more severe. In short, compared with the situation of strong political connection, the investment level and overinvestment of debt restructuring enterprises with weak political connection are apparently lower.

4.2. Correlation Analysis. Table 4 reports the correlation matrix between variables. The Spearman correlation coefficients are above the leading diagonal, and the Pearson correlation coefficients are below the leading diagonal. From the correlation results, there is a significant positive correlation between investment expenditure and investment efficiency under the two correlations. The investment variables are negatively correlated with leverage ratio, listing time, enterprise size, and board size, while positively correlated with cash flow, Tobin's $Q$, equity balance, regulators holdings, and director independence. Moreover, the values of the correlation coefficients are all less than 0.300 . Therefore, we believe that there is no collinearity problem between variables.

\subsection{Political Connections, Debt Restructuring, and Enterprise} Investment. Table 5 reports the empirical results of political connections, debt restructuring, and enterprise investment. As mentioned above, we first use the binary variable GI to test the influence of political connections on the relationship between debt restructuring and enterprise investment. All of the models in Table 5 control for year and industry effects, and the first two models contain only the variables of debt restructuring and political connections. From the first two columns, the coefficient of the interaction DRD $\times$ TIME $\times$ GI for the investment expenditure is not significant, while the coefficient of $\mathrm{DRD} \times \mathrm{TIME} \times \mathrm{GI}$ for the investment efficiency is significantly negative at the statistical level of 5\%. After controlling the control variables, the interaction coefficient for the investment efficiency is still negative $(-0.020)$ and statistically significant at $1 \%$, indicating that compared with the nonpolitical connection enterprises, the debt restructuring in politically connected enterprises notably improves the investment efficiency. Furtherly, the coefficients of interaction we focus on in columns (5)-(6) are statistically significantly negative $(-0.032,-0.018)$ at $10 \%$ and $5 \%$, respectively, suggesting that for enterprises with political ties, debt restructuring prominently improves the investment efficiency by alleviating overinvestment and underinvestment. In other words, debt restructuring in politically connected enterprises has a positive mitigating effect on both overinvestment and underinvestment.

Table 6 reports the empirical results of strength of political connection, debt restructuring, and enterprise investment. The binary variable MI1 is used to test the influence of strength of political connection on the link 
TABLE 1: Definition of variables used in this paper.

\begin{tabular}{|c|c|c|}
\hline Names & Notation & Definition \\
\hline Investment expenditure & INV & Ratio of capital expenditure to total assets. \\
\hline Investment efficiency & ABSINV & $\begin{array}{l}\text { ABSINV is the absolute value of the residual term of regression in which the newly } \\
\text { increased investment in the current period is the dependent variable, indicating the } \\
\text { investment efficiency. The larger the value, the greater the deviation between the } \\
\text { actual investment and the expected investment, which means lower investment } \\
\text { efficiency. }\end{array}$ \\
\hline Overinvestment & EXINV & $\begin{array}{l}\text { EXINV is a residual term above } 0 \text {, that is, the actual investment is greater than the } \\
\text { expected investment, indicating overinvestment. The higher the value, the more } \\
\text { severe of overinvestment. }\end{array}$ \\
\hline Underinvestment & UNINV & $\begin{array}{l}\text { UNINV is the residual term below } 0 \text {, that is, the actual investment is below the } \\
\text { expected investment, and its absolute value is used to measure the underinvestment. } \\
\text { The higher the value, the more severe of underinvestment. }\end{array}$ \\
\hline $\begin{array}{l}\text { The dummy variable for debt } \\
\text { restructuring }\end{array}$ & DRD & $\begin{array}{l}\text { Represents the dummy variable for debt restructuring, which is equal to } 1 \text { if an } \\
\text { enterprise carries out debt restructuring, otherwise it is } 0 .\end{array}$ \\
\hline $\begin{array}{l}\text { The dummy variable for the period of } \\
\text { debt restructuring }\end{array}$ & TIME & $\begin{array}{l}\text { Represents a dummy variable for the period of debt restructuring, with a value equal } \\
\text { to } 0 \text { for the period before debt restructuring and } 1 \text { for the period after debt } \\
\text { restructuring. }\end{array}$ \\
\hline Political connection & GI & $\begin{array}{l}\text { If an enterprise's CEO or chairman is or has been a government official, provincial, or } \\
\text { ministerial politician, or military officer, the enterprise is considered politically } \\
\text { connected, and the dummy variable equals } 1 \text {, otherwise } 0 .\end{array}$ \\
\hline Strength of political connection & MI1 & $\begin{array}{l}\text { It is divided into low, middle, and high levels based on the government index. If the } \\
\text { strength of political connection is low, the dummy variable equals } 1 \text {, otherwise } 0 \text {. }\end{array}$ \\
\hline Leverage ratio & LEV & Ratio of total liabilities to total assets. \\
\hline Cash flow & CF & Balance of cash and cash equivalents at the end of the period. \\
\hline Tobin's Q & Q & $($ Market value of equity + total liabilities $) /$ total assets \\
\hline Equity balance & CSTR & $\begin{array}{l}\text { Logarithmic sum of squares of shareholdings of the second to tenth largest } \\
\text { shareholders. }\end{array}$ \\
\hline Director independence & RID & Ratio of number of independent directors to total number of directors. \\
\hline Regulators holdings & ESH & Management shareholding ratio. \\
\hline Board size & BOARD & Total number of directors. \\
\hline Listing time & AGE & Listing time of the enterprise. \\
\hline Enterprise size & SIZE & Natural logarithm of total assets. \\
\hline
\end{tabular}

TABLE 2: Balance hypothesis test in PSM.

\begin{tabular}{|c|c|c|c|c|c|c|c|}
\hline \multirow{2}{*}{ Variable } & \multirow{2}{*}{ Matching } & \multicolumn{2}{|c|}{ Mean difference test } & \multicolumn{2}{|c|}{ Standard deviation test } & \multirow{2}{*}{ T-test } & \multirow{2}{*}{$P$ value } \\
\hline & & Mean of treatment group & Mean of control group & $\mathrm{SD}$ & Reduction (\%) & & \\
\hline \multirow{2}{*}{ LEV } & Pre & 0.724 & 0.469 & 109.200 & \multirow{2}{*}{98.500} & 18.180 & 0.0001 \\
\hline & Post & 0.724 & 0.720 & 1.700 & & 0.180 & 0.859 \\
\hline \multirow{2}{*}{ SIZE } & Pre & 20.996 & 21.686 & -54.000 & \multirow{2}{*}{96.300} & -8.500 & 0.0001 \\
\hline & Post & 20.996 & 20.971 & 2.000 & & 0.210 & 0.831 \\
\hline \multirow{2}{*}{ AGE } & Pre & 2.323 & 1.942 & 53.000 & \multirow{2}{*}{95.600} & 6.920 & 0.0001 \\
\hline & Post & 2.323 & 2.340 & -2.300 & & -0.340 & 0.734 \\
\hline \multirow{2}{*}{ CSTR } & Pre & -5.086 & -5.169 & 4.500 & \multirow{2}{*}{87.600} & 0.670 & 0.503 \\
\hline & Post & -5.086 & -5.096 & 0.600 & & 0.070 & 0.948 \\
\hline \multirow{2}{*}{ ESH } & Pre & 0.007 & 0.059 & -49.900 & \multirow[b]{2}{*}{97.200} & -5.680 & 0.0001 \\
\hline & Post & 0.007 & 0.009 & -1.400 & & -0.350 & 0.725 \\
\hline \multirow{2}{*}{ ROA } & Pre & -0.015 & 0.041 & -66.800 & \multirow{2}{*}{88.400} & -14.190 & 0.0001 \\
\hline & Post & -0.015 & -0.022 & 7.800 & & 0.710 & 0.477 \\
\hline \multirow{2}{*}{ Pseudo $R^{2}$} & Pre & \multirow{2}{*}{\multicolumn{2}{|c|}{$\begin{array}{l}0.164 \\
0.002 \\
\end{array}$}} & & \multirow{2}{*}{\multicolumn{3}{|c|}{$\begin{array}{c}417.750(0.0001) \\
1.380(0.967) \\
\end{array}$}} \\
\hline & Post & & & LR( $P$ value $)$ & & & \\
\hline
\end{tabular}

Note. The matching method used in Table 2 is the nearest neighbor matching method $(k=10)$. 


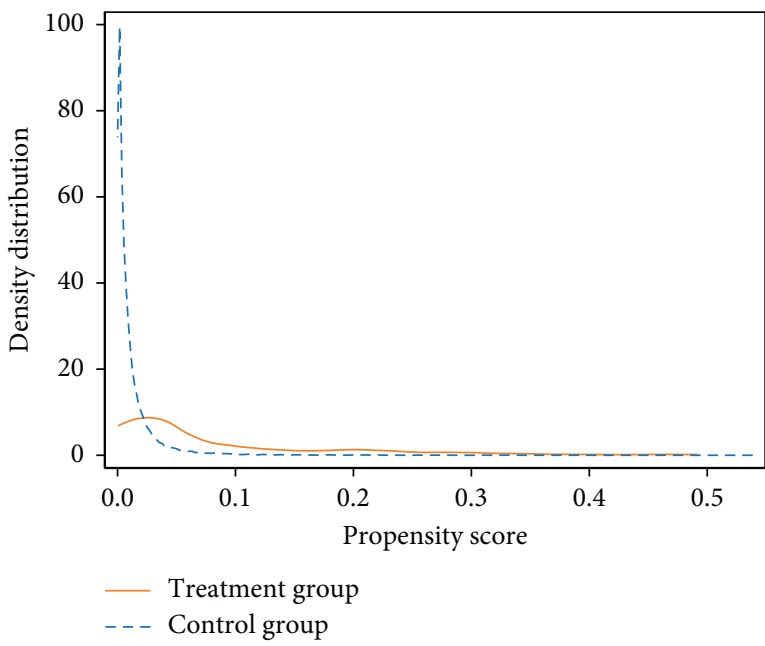

(a)

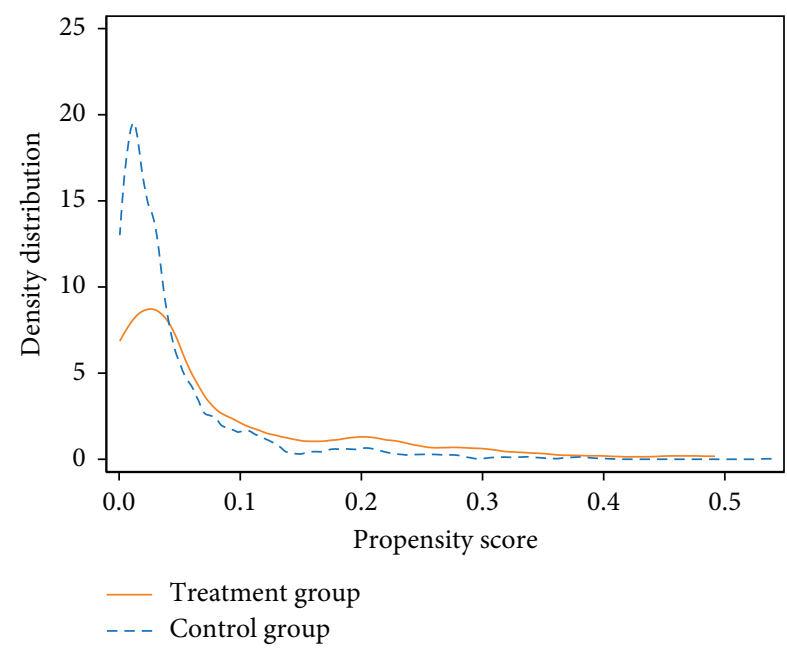

(b)

Figure 1: Probability density distribution before and after matching. (a) Pre and (b) post.

Table 3: Descriptive statistics.

\begin{tabular}{lcccccccccc}
\hline \multirow{2}{*}{ Variables } & \multicolumn{4}{c}{ Nondebt restructuring enterprises } & \multicolumn{4}{c}{ Debt restructuring enterprises } \\
& Min & Max & Mean & Median & Standard deviation & Min & Max & Mean & Median & Standard deviation \\
\hline INV & -0.093 & 0.425 & 0.039 & 0.012 & 0.081 & -0.093 & 0.425 & 0.008 & -0.002 & 0.067 \\
ABSINV & 0.000 & 0.448 & 0.051 & 0.035 & 0.058 & 0.000 & 0.403 & 0.049 & 0.032 & 0.055 \\
EXINV & 0.000 & 0.448 & 0.068 & 0.036 & 0.084 & 0.000 & 0.403 & 0.058 & 0.021 & 0.085 \\
UNINV & 0.000 & 0.210 & 0.041 & 0.034 & 0.030 & 0.001 & 0.190 & 0.045 & 0.036 & 0.034 \\
LEV & 0.052 & 1.065 & 0.469 & 0.473 & 0.216 & 0.089 & 1.065 & 0.724 & 0.707 & 0.250 \\
CF & 0.000 & 0.607 & 0.139 & 0.099 & 0.130 & 0.000 & 0.607 & 0.062 & 0.026 & 0.091 \\
Q & 0.898 & 12.859 & 2.560 & 1.938 & 1.939 & 0.898 & 12.859 & 3.421 & 2.146 & 3.188 \\
AGE & 0.000 & 3.091 & 1.945 & 2.197 & 0.850 & 0.000 & 3.091 & 2.323 & 2.398 & 0.555 \\
SIZE & 19.016 & 25.596 & 21.683 & 21.535 & 1.248 & 19.016 & 25.029 & 20.996 & 20.995 & 1.303 \\
CSTR & -10.260 & -2.208 & -5.171 & -4.839 & 1.904 & -10.260 & -2.208 & -5.086 & -4.737 & 1.721 \\
ESH & 0.000 & 0.622 & 0.059 & 0.000 & 0.141 & 0.000 & 0.396 & 0.007 & 0.000 & 0.040 \\
RID & 0.286 & 0.571 & 0.367 & 0.333 & 0.051 & 0.286 & 0.571 & 0.366 & 0.333 & 0.049 \\
BOARD & 3.000 & 19.000 & 8.999 & 9.000 & 1.845 & 4.000 & 15.000 & 8.855 & 9.000 & 1.880 \\
\hline
\end{tabular}

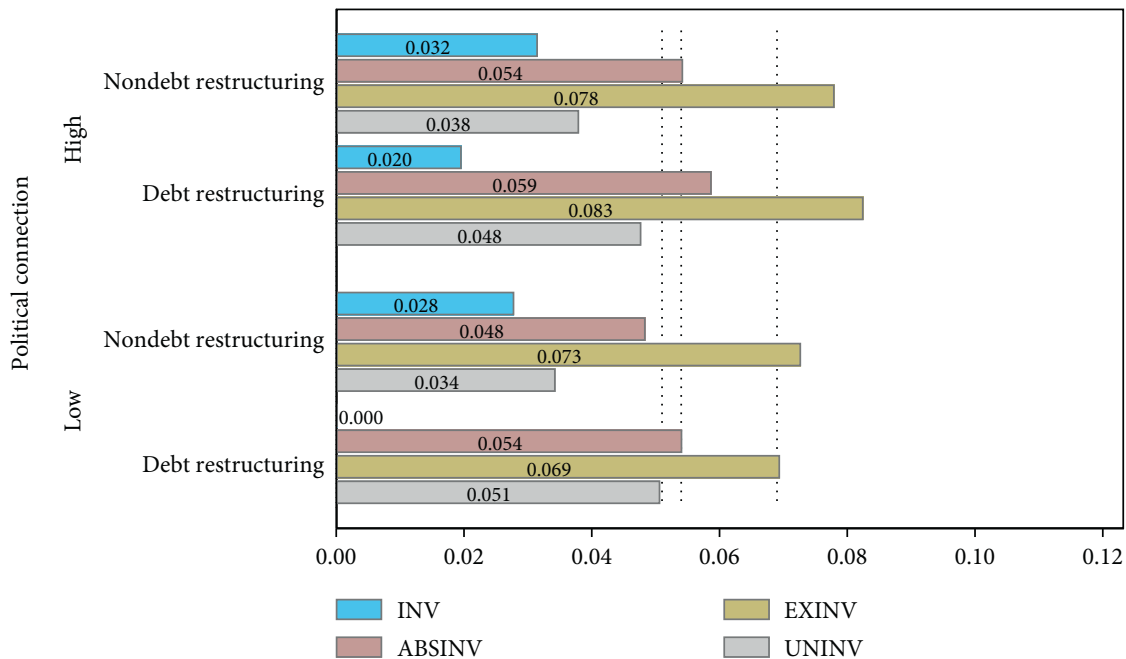

FIGURE 2: The enterprises' investment situation under different strength of political connection. 
TABle 4: Spearman-Pearson correlation matrix.

\begin{tabular}{lccccccccccc}
\hline & INV & ABSINV & LEV & CF & Q & AGE & SIZE & CSTR & ESH & RID & BOARD \\
\hline INV & 1.000 & $0.112^{*}$ & $-0.165^{*}$ & $0.205^{*}$ & $0.112^{*}$ & $-0.251^{*}$ & -0.001 & $0.120^{*}$ & $0.157^{*}$ & 0.013 & 0.003 \\
ABSINV & $0.701^{*}$ & 1.000 & $-0.235^{*}$ & $0.142^{*}$ & $0.283^{*}$ & $-0.160^{*}$ & $-0.257^{*}$ & $0.093^{*}$ & $0.136^{*}$ & $0.036^{*}$ & $-0.092^{*}$ \\
LEV & $-0.125^{*}$ & $-0.101^{*}$ & 1.000 & $-0.413^{*}$ & $-0.378^{*}$ & $0.345^{*}$ & $0.292^{*}$ & $-0.152^{*}$ & $-0.314^{*}$ & $-0.016^{*}$ & $0.144^{*}$ \\
CF & $0.129^{*}$ & $0.100^{*}$ & $-0.436^{*}$ & 1.000 & $0.186^{*}$ & $-0.252^{*}$ & $-0.076^{*}$ & $0.109^{*}$ & $0.218^{*}$ & $0.020^{*}$ & $-0.053^{*}$ \\
Q & $0.112^{*}$ & $0.236^{*}$ & $-0.218^{*}$ & $0.166^{*}$ & 1.000 & $-0.134^{*}$ & $-0.434^{*}$ & $0.130^{*}$ & $0.217^{*}$ & $0.044^{*}$ & $-0.178^{*}$ \\
AGE & $-0.193^{*}$ & $-0.092^{*}$ & $0.376^{*}$ & $-0.320^{*}$ & $-0.067^{*}$ & 1.000 & $0.232^{*}$ & $-0.317^{*}$ & $-0.409^{*}$ & $-0.015^{*}$ & $0.055^{*}$ \\
SIZE & $-0.044^{*}$ & $-0.155^{*}$ & $0.258^{*}$ & $-0.126^{*}$ & $-0.383^{*}$ & $0.205^{*}$ & 1.000 & $-0.085^{*}$ & $-0.099^{*}$ & $0.033^{*}$ & $0.216^{*}$ \\
CSTR & $0.100^{*}$ & $0.063^{*}$ & $-0.144^{*}$ & $0.130^{*}$ & $0.115^{*}$ & $-0.329^{*}$ & $-0.059^{*}$ & 1.000 & $0.236^{*}$ & $0.017^{*}$ & $0.020^{*}$ \\
ESH & $0.121^{*}$ & $0.085^{*}$ & $-0.332^{*}$ & $0.259^{*}$ & $0.135^{*}$ & $-0.513^{*}$ & $-0.151^{*}$ & $0.256^{*}$ & 1.000 & $0.068^{*}$ & $-0.166^{*}$ \\
RID & $0.018^{*}$ & $0.032^{*}$ & $-0.017^{*}$ & $0.025^{*}$ & $0.070^{*}$ & $-0.031^{*}$ & $0.052^{*}$ & 0.007 & $0.098^{*}$ & 1.000 & $-0.397^{*}$ \\
BOARD & $-0.016^{*}$ & $-0.065^{*}$ & $0.139^{*}$ & $-0.075^{*}$ & $-0.162^{*}$ & $0.072^{*}$ & $0.249^{*}$ & $0.015^{*}$ & $-0.175^{*}$ & $-0.378^{*}$ & 1.000 \\
\hline
\end{tabular}

Note. *Statistical significance at the $5 \%$ levels. The Spearman correlation coefficients are above the leading diagonal, and the Pearson correlation coefficients are below the leading diagonal.

Table 5: Political connections, debt restructuring, and enterprise investment.

\begin{tabular}{|c|c|c|c|c|c|c|}
\hline & & & & & & \\
\hline & $(1)$ & (2) & $(3)$ & (4) & (5) & (6) \\
\hline & INV & ABSINV & INV & ABSINV & EXINV & UNINV \\
\hline $\mathrm{DRD} \times \mathrm{TIME} \times \mathrm{GI}$ & $\begin{array}{l}-0.006 \\
(-0.41)\end{array}$ & $\begin{array}{c}-0.027^{* *} \\
(-3.01)\end{array}$ & $\begin{array}{l}0.004 \\
(0.35)\end{array}$ & $\begin{array}{c}-0.020^{* * *} \\
(-4.86)\end{array}$ & $\begin{array}{c}-0.032^{*} \\
(-1.95)\end{array}$ & $\begin{array}{c}-0.018^{* *} \\
(-2.58)\end{array}$ \\
\hline $\mathrm{DRD} \times \mathrm{TIME}$ & $\begin{array}{c}-0.012^{*} \\
(-2.22)\end{array}$ & $\begin{array}{l}0.009 \\
(1.57)\end{array}$ & $\begin{array}{c}-0.013^{* *} \\
(-2.86)\end{array}$ & $\begin{array}{l}-0.006 \\
(-1.05)\end{array}$ & $\begin{array}{l}-0.011 \\
(-1.32)\end{array}$ & $\begin{array}{c}0.001 \\
(0.30)\end{array}$ \\
\hline $\mathrm{DRD} \times \mathrm{GI}$ & $\begin{array}{c}0.010 \\
(0.85)\end{array}$ & $\begin{array}{c}0.021^{* * * *} \\
(7.97)\end{array}$ & $\begin{array}{l}0.007 \\
(0.56)\end{array}$ & $\begin{array}{c}0.024^{* * *} \\
(17.03)\end{array}$ & $\begin{array}{c}0.036^{* * *} \\
(4.57)\end{array}$ & $\begin{array}{c}0.016^{* *} \\
(2.69)\end{array}$ \\
\hline TIME $\times$ GI & $\begin{array}{l}0.014^{*} \\
(2.00)\end{array}$ & $\begin{array}{l}-0.000 \\
(-0.01)\end{array}$ & $\begin{array}{l}0.011 \\
(1.49)\end{array}$ & $\begin{array}{l}0.002 \\
(0.79)\end{array}$ & $\begin{array}{c}0.001 \\
(0.24)\end{array}$ & $\begin{array}{l}-0.002 \\
(-0.52)\end{array}$ \\
\hline LEV & & & $\begin{array}{l}-0.014 \\
(-1.84)\end{array}$ & $\begin{array}{c}0.015^{* *} \\
(2.49)\end{array}$ & $\begin{array}{r}0.052^{*} \\
(214)\end{array}$ & $\begin{array}{l}-0.003 \\
(-0.58)\end{array}$ \\
\hline $\mathrm{CF}$ & & & $\begin{array}{l}0.070 \\
(1.56)\end{array}$ & $\begin{array}{l}0.029 \\
(1.11)\end{array}$ & $\begin{array}{l}0.069 \\
(0.81)\end{array}$ & $\begin{array}{c}0.016^{* *} \\
(2.43)\end{array}$ \\
\hline Q & & & $\begin{array}{c}0.005^{* *} \\
(2.53)\end{array}$ & $\begin{array}{c}0.006^{* * *} \\
(3.87)\end{array}$ & $\begin{array}{c}0.012^{* * *} \\
(5.54)\end{array}$ & $\begin{array}{c}0.004^{* * *} \\
(9.87)\end{array}$ \\
\hline AGE & & & $\begin{array}{c}-0.012^{* * *} \\
(-9.83)\end{array}$ & $\begin{array}{l}-0.004 \\
(-1.62)\end{array}$ & $\begin{array}{l}-0.003 \\
(-0.38)\end{array}$ & $\begin{array}{c}-0.004^{* *} \\
(-2.92)\end{array}$ \\
\hline SIZE & & & $\begin{array}{c}0.005^{* *} \\
(2.67)\end{array}$ & $\begin{array}{c}-0.006^{* *} \\
(-3.20)\end{array}$ & $\begin{array}{c}-0.013^{* * *} \\
(-5.40)\end{array}$ & $\begin{array}{c}-0.010^{* * *} \\
(-14.58)\end{array}$ \\
\hline CSTR & & & $\begin{array}{l}0.001 \\
(1.67)\end{array}$ & $\begin{array}{c}0.001 \\
(0.98)\end{array}$ & $\begin{array}{l}-0.000 \\
(-0.11)\end{array}$ & $\begin{array}{l}0.000 \\
(1.22)\end{array}$ \\
\hline ESH & & & $\begin{array}{l}-0.027 \\
(-0.98)\end{array}$ & $\begin{array}{l}-0.028 \\
(-1.16)\end{array}$ & $\begin{array}{l}-0.003 \\
(-0.04)\end{array}$ & $\begin{array}{c}-0.017^{* *} \\
(-2.73)\end{array}$ \\
\hline RID & & & $\begin{array}{l}-0.000 \\
(-0.01)\end{array}$ & $\begin{array}{c}0.028 \\
(0.98)\end{array}$ & $\begin{array}{l}-0.012 \\
(-0.22)\end{array}$ & $\begin{array}{l}0.024 \\
(1.22)\end{array}$ \\
\hline BOARD & & & $\begin{array}{c}-0.003^{* *} \\
(-2.75)\end{array}$ & $\begin{array}{c}-0.001^{* * *} \\
(-3.54)\end{array}$ & $\begin{array}{c}-0.004^{* *} \\
(-2.94)\end{array}$ & $\begin{array}{l}0.000 \\
(0.67)\end{array}$ \\
\hline Year effect & Yes & Yes & Yes & Yes & Yes & Yes \\
\hline Industry effect & Yes & Yes & Yes & Yes & Yes & Yes \\
\hline Obs. & 1527 & 1527 & 1527 & 1527 & 548 & 979 \\
\hline$R^{2}$ & 0.050 & 0.068 & 0.082 & 0.151 & 0.259 & 0.380 \\
\hline$F$ value & 20.938 & 22.957 & 19.680 & 11.356 & 48.923 & 29.950 \\
\hline$P$ value & 0.0001 & 0.0001 & 0.0001 & 0.001 & 0.0001 & 0.0001 \\
\hline
\end{tabular}

Note. The $t$ statistics appear in parentheses. ${ }^{*},{ }^{* *}$, and ${ }^{* * *}$ Statistical significance at the $10 \%, 5 \%$, and $1 \%$ levels, respectively. 
TABLE 6: Strength of political connection, debt restructuring, and enterprise investment.

\begin{tabular}{|c|c|c|c|c|c|c|}
\hline & & & & & & \\
\hline & (1) & (2) & (3) & (4) & (5) & (6) \\
\hline & INV & ABSINV & INV & ABSINV & EXINV & UNINV \\
\hline $\mathrm{DRD} \times \mathrm{TIME} \times \mathrm{MI} 1$ & $\begin{array}{c}-0.091^{* * *} \\
(-5.11)\end{array}$ & $\begin{array}{c}-0.063^{* * *} \\
(-7.10)\end{array}$ & $\begin{array}{c}-0.084^{* * *} \\
(-4.93)\end{array}$ & $\begin{array}{c}-0.051^{* * *} \\
(-6.05)\end{array}$ & $\begin{array}{c}-0.062^{* * *} \\
(-3.70)\end{array}$ & $\begin{array}{c}-0.019^{*} \\
(-2.08)\end{array}$ \\
\hline $\mathrm{DRD} \times \mathrm{TIME}$ & $\begin{array}{c}0.062^{* * *} \\
(4.88)\end{array}$ & $\begin{array}{c}0.034^{* * *} \\
(6.97)\end{array}$ & $\begin{array}{c}0.052^{* * *} \\
(4.15)\end{array}$ & $\begin{array}{c}0.022^{* * *} \\
(3.78)\end{array}$ & $\begin{array}{l}-0.004 \\
(-0.51)\end{array}$ & $\begin{array}{c}0.014^{* *} \\
(2.33)\end{array}$ \\
\hline $\mathrm{DRD} \times \mathrm{MI} 1$ & $\begin{array}{c}0.028^{*} \\
(2.24) \\
\end{array}$ & $\begin{array}{c}0.030^{* *} \\
(2.82)\end{array}$ & $\begin{array}{l}0.020 \\
(1.43)\end{array}$ & $\begin{array}{c}0.017^{*} \\
(1.89)\end{array}$ & $\begin{array}{l}0.025 \\
(1.18)\end{array}$ & $\begin{array}{l}-0.001 \\
(-0.23)\end{array}$ \\
\hline TIME $\times$ MI1 & $\begin{array}{c}0.030^{* *} \\
(2.84)\end{array}$ & $\begin{array}{c}0.004 \\
(0.38) \\
\end{array}$ & $\begin{array}{c}0.028^{* *} \\
(2.73)\end{array}$ & $\begin{array}{l}0.003 \\
(0.36) \\
\end{array}$ & $\begin{array}{l}-0.000 \\
(-0.05)\end{array}$ & $\begin{array}{c}0.006^{*} \\
(2.16)\end{array}$ \\
\hline LEV & & & $\begin{array}{l}-0.005 \\
(-0.28)\end{array}$ & $\begin{array}{l}-0.000 \\
(-0.01)\end{array}$ & $\begin{array}{c}0.048^{*} \\
(2.04)\end{array}$ & $\begin{array}{l}-0.004 \\
(-0.49)\end{array}$ \\
\hline $\mathrm{CF}$ & & & $\begin{array}{l}0.051 \\
(1.10) \\
\end{array}$ & $\begin{array}{l}0.018 \\
(1.31)\end{array}$ & $\begin{array}{l}0.062 \\
(0.69)\end{array}$ & $\begin{array}{c}0.023^{* *} \\
(2.32)\end{array}$ \\
\hline Q & & & $\begin{array}{c}0.006^{* *} \\
(2.88) \\
\end{array}$ & $\begin{array}{c}0.008^{* * *} \\
(4.66)\end{array}$ & $\begin{array}{c}0.012^{* * *} \\
(5.81)\end{array}$ & $\begin{array}{c}0.005^{* * *} \\
(7.38)\end{array}$ \\
\hline AGE & & & $\begin{array}{c}-0.050^{* * *} \\
(-5.81)\end{array}$ & $\begin{array}{c}-0.026^{* * *} \\
(-3.58)\end{array}$ & $\begin{array}{l}-0.003 \\
(-0.49) \\
\end{array}$ & $\begin{array}{c}0.010^{* * *} \\
(3.46)\end{array}$ \\
\hline SIZE & & & $\begin{array}{l}-0.004 \\
(-0.60)\end{array}$ & $\begin{array}{l}-0.012 \\
(-1.83)\end{array}$ & $\begin{array}{c}-0.013^{* * *} \\
(-5.57)\end{array}$ & $\begin{array}{r}-0.010^{* * *} \\
(-6.33)\end{array}$ \\
\hline CSTR & & & $\begin{array}{l}-0.002 \\
(-1.58)\end{array}$ & $\begin{array}{l}-0.001 \\
(-0.69)\end{array}$ & $\begin{array}{l}-0.000 \\
(-0.03) \\
\end{array}$ & $\begin{array}{l}0.001 \\
(1.58) \\
\end{array}$ \\
\hline ESH & & & $\begin{array}{l}0.021 \\
(0.17)\end{array}$ & $\begin{array}{c}-0.139^{* *} \\
(-2.79)\end{array}$ & $\begin{array}{l}-0.000 \\
(-0.00)\end{array}$ & $\begin{array}{c}-0.153^{*} \\
(-2.21)\end{array}$ \\
\hline RID & & & $\begin{array}{l}-0.036 \\
(-0.75) \\
\end{array}$ & $\begin{array}{l}0.040 \\
(0.73) \\
\end{array}$ & $\begin{array}{l}-0.009 \\
(-0.15) \\
\end{array}$ & $\begin{array}{l}0.032 \\
(1.29) \\
\end{array}$ \\
\hline BOARD & & & $\begin{array}{l}-0.003 \\
(-1.38) \\
\end{array}$ & $\begin{array}{l}-0.001 \\
(-0.45)\end{array}$ & $\begin{array}{c}-0.004 * * \\
(-2.95)\end{array}$ & $\begin{array}{l}0.001 \\
(1.31)\end{array}$ \\
\hline Year effect & Yes & Yes & Yes & Yes & Yes & Yes \\
\hline Industry effect & Yes & Yes & Yes & Yes & Yes & Yes \\
\hline Obs. & 1527 & 1527 & 1527 & 1527 & 548 & 979 \\
\hline$R^{2}$ & 0.058 & 0.061 & 0.092 & 0.167 & 0.260 & 0.266 \\
\hline$F$ value & 25.781 & 191.327 & 65.282 & 1318.311 & 81.289 & 136.574 \\
\hline$P$ value & 0.0001 & 0.0001 & 0.0001 & 0.0001 & 0.0001 & 0.0001 \\
\hline
\end{tabular}

Note. The $t$ statistics appear in parentheses. ${ }^{*},{ }^{* *}$, and ${ }^{* * *}$ Statistical significance at the $10 \%, 5 \%$, and $1 \%$ levels, respectively.

between debt restructuring and investment (recall that MI1 equals 1 if the strength of political connection is low, otherwise 0 ). All of the models in Table 6 control for year and industry effects, and the first two models include only the variables of debt restructuring and political connection. From columns (1)-(2), the coefficients of the interaction $\mathrm{DRD} \times \mathrm{TIME} \times \mathrm{MI} 1$ for the investment expenditure and investment efficiency are negative and the significance level is $1 \%$. Columns (3)-(6) consider the control variables based on the first two columns. The interaction coefficients we focus on for investment expenditure and investment efficiency are still significantly negative at the significance level of $1 \%(-0.084,-0.051)$, which means that compared with enterprises with strong political connection, debt restructuring significantly reduces investment expenditure and improves investment efficiency in enterprises with weak political connection. Furthermore, the interaction coefficients that we are interested in, in columns (5)-(6), are statistically significantly negative at $1 \%$ and $10 \%(-0.062$, $-0.019)$, respectively. This indicates that the debt restructuring significantly mitigates the problem of overinvestment and underinvestment in enterprises with weak political connection, thus improving the investment efficiency.

Therefore, it can be concluded that political connections have a significant impact on the relationship between debt restructuring and enterprise investment. Specifically, debt restructuring plays a positive role on investment efficiency in political connection enterprises, which is mainly due to the evident alleviation of overinvestment and underinvestment. In terms of the strength of political connection, debt restructuring generally has a positive effect on investment in enterprises with weak political connection than those with strong connection. On the one hand, debt restructuring significantly curbs overinvestment; on the other hand, debt restructuring plays a positive role in alleviating 
underinvestment. Therefore, the investment efficiency of enterprises with weak political connection is significantly improved on the whole. So, the empirical results support the research hypothesis proposed above.

This paper examines the relationship between debt restructuring and enterprise investment from two progressive perspectives: whether it is politically connected and strength of political connection. The results show that political connection, as a nonnegligible external governance mechanism, has an important role on the relationship between debt restructuring and enterprise investment. Compared with nonpolitically connected enterprises, debt restructuring effectively reduces inefficiency investment (that is, significantly alleviating overinvestment and underinvestment) in the enterprises with political ties. It is worth noting that the positive impact of debt restructuring on enterprise investment is only shown in enterprises with weak political connection. With the increase of connection strength, the positive effect of debt restructuring on investment will disappear, which reflects the heterogeneity of the impact of strength of political connection on the link between debt restructuring and enterprise investment.

We believe that political connection is an influential mechanism to explain the relationship between debt restructuring and investment. In emerging economies such as China, politically connected enterprises tend to make inefficient investments. On the one hand, because of the convenience of political connection, politically connected enterprises have inherent advantages in accepting government subsidies, preferential credit, tax rates, government contracts, and other aspects [18]. Such conditions can provide politically connected enterprises with low-cost capital and less asset liquidity constraint, which enhances the motivation of enterprises to overinvest. On the other hand, managers of politically connected enterprises often have greater incentives to make overinvestments to achieve outstanding performance and further promote their positions. Therefore, enterprise with political ties tend to deviate from the goal of maximizing enterprise value and make inefficient investment. The debt restructuring in politically connected enterprises, on the one hand, will prompt the government and lenders, such as financial institutions, to make a cautious assessment of the funds and channels obtained by enterprises and increase the supervision over the capital use and project risks of restructuring enterprises. On the other hand, it can interpose in the operation decisions of enterprises with debt restructuring, such as evaluating and controlling the risks of investment strategy and imposing restrictive clauses, so as to help curb the overinvestment behaviour caused by the advantage of political connections [29]. At the same time, the restructuring income from debt restructuring alleviates the liquidity crisis to a certain extent, which is conducive to alleviating the underinvestment. In addition, debt restructuring can produce effective vigilance and self-correction effect on the managers of politically connected enterprises, making them make more rational decisions, which will help improve the investment efficiency.
4.4. Robustness Checks. In order to enhance the reliability and validity of the results, we conduct the robustness test. The above analysis illustrates the impact of strength of political connection on the relationship between debt restructuring and enterprise investment based on the perspective of weak political connection, and the dummy variable MI1 is set according to the trisection of the government index. In order to show that the empirical results are not sensitive to the definition of political connection degree, the impact of connection strength on the link between debt restructuring and investment is tested by changing the setting of MI1 and from the opposite perspective (i.e., strong political connection). Specifically, we know that the stronger the intervention of local governments in enterprises within their jurisdictions, the smaller the value of the government index. If the headquarter of an enterprise is located in a region where the political connection is stronger than the annual median, that is, the government index is less than the annual median, then the enterprise is considered to have a strong political connection, and MI1 equals 1 , vice versa, the value is 0 . If the empirical results show that debt restructuring significantly increases investment expenditure and has a negative impact on investment efficiency, overinvestment, and underinvestment for enterprises with strong political connection, it means that the results obtained above are robust.

The empirical results of robustness test are reported in Table 7, and each model controls for year and industry effect. Control variables are not considered in the model of the first two columns, and the coefficients of the interaction $\mathrm{DRD} \times \mathrm{TIME} \times \mathrm{MI} 1$ we are concerned with are significantly positive. Columns (3)-(6) further control the financial variables, governance variables, and enterprise characteristic variables based on the first two columns. The coefficients of the interaction DRD $\times$ TIME $\times$ MI1 for investment expenditure and investment efficiency are positive $(0.045,0.047)$ and statistically significant at $5 \%$ and $1 \%$, respectively, indicating that debt restructuring prominently increases investment level but decreases investment efficiency in enterprises with strong political connection. In fact, the interaction coefficients in columns (5)-(6) that we focus on are all significantly positive $(0.034$, 0.019 ) at the level of $5 \%$, suggesting that compared with enterprises with weak political connection, debt restructuring has a negative effect on both overinvestment and underinvestment in enterprises with strong political connection, thus reducing investment efficiency. As we know, intervention by politicians for political interest is more convenient in the enterprise with strong political connection, and the negative effect of "grabbing hand" is reinforced, which distorts the aim of enterprise value maximization and inevitably has an adverse effect on investment efficiency that outweighs the positive monitoring effect of debt restructuring. Therefore, the change in the measurement of strength of political connection does not qualitatively affect the empirical results, and the results obtained above are robust. 
TABLE 7: The results of robustness checks.

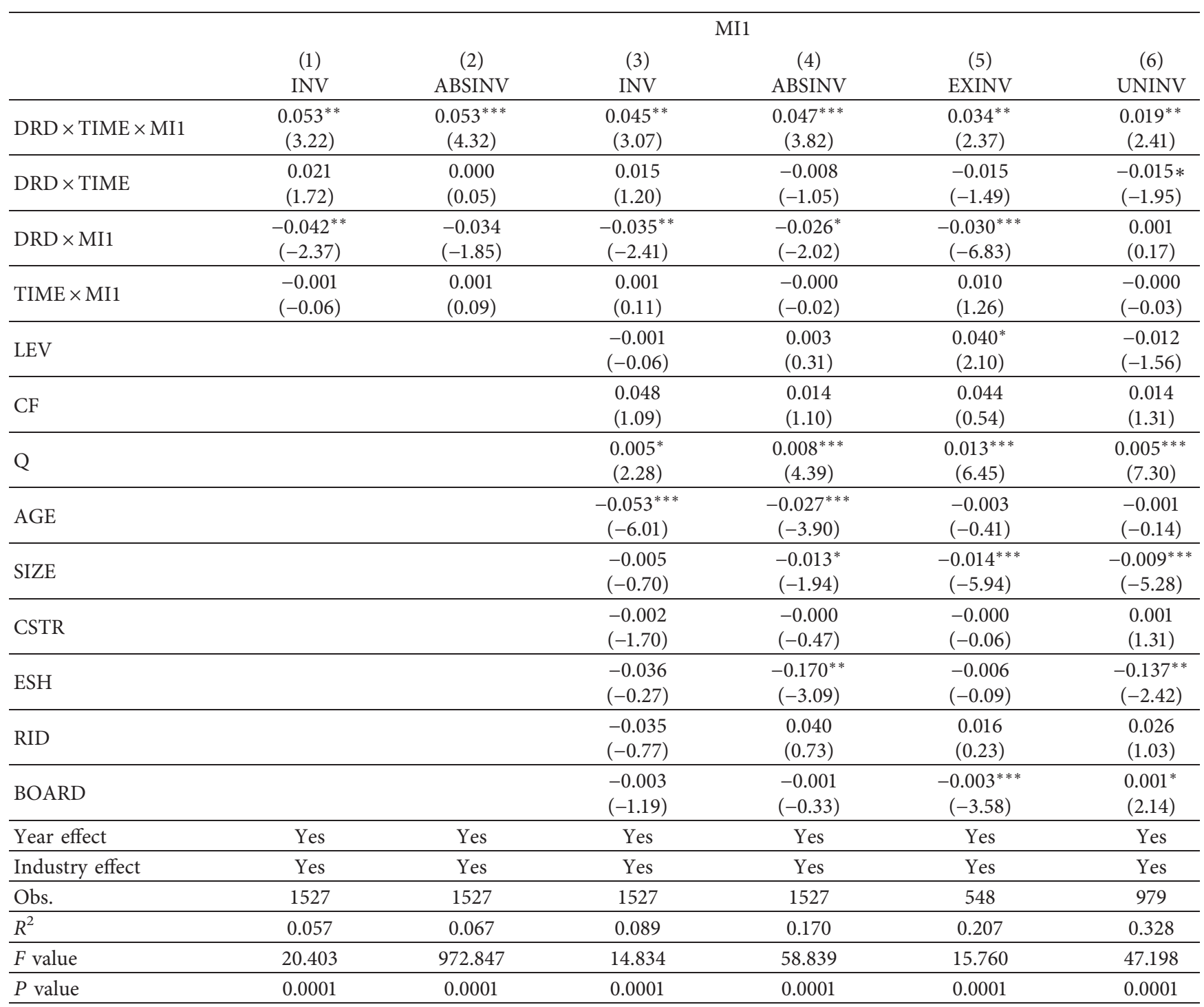

Note. The $t$ statistics appear in parentheses. ${ }^{*},{ }^{* *}$, and ${ }^{* * *}$ Statistical significance at the $10 \%, 5 \%$, and $1 \%$ levels, respectively.

\section{Conclusions}

In this study, taking the nonfinancial A-share enterprises listed in China from 2005 to 2016 as samples, we show the evidence of the impact of political connections on the relation between debt restructuring and enterprise investment in emerging market economies. The results show that political connections make the relationship between debt restructuring and enterprise investment have significant heterogeneity. Specifically, compared with nonpolitically connected enterprises, debt restructuring notably alleviates overinvestment and underinvestment in political connection enterprises, thus significantly improving investment efficiency. Furthermore, the positive effect of debt restructuring on investment is more prominent in enterprises with weak political connection. It is worth noting that as the strength of political connection increases from weak to strong, the positive impact of debt restructuring on investment turns to negative impact, which reflects the heterogeneity of the impact of connection strength on the relation between debt restructuring and investment. In conclusion, the political connections of Chinese enterprises have a significant impact on the relationship between debt restructuring and enterprise investment.

The results of this paper enrich the existing research systems of debt restructuring and investment, deepen the understanding of the investment behaviour of enterprises with debt restructuring, and have guiding significance to improve investment efficiency. Although some studies have focused on the potential impact of debt restructuring on investment, little is known about the impact of political connections in emerging markets on the relationship between debt restructuring and investment. The results have crucial implications for understanding the role of political connections. The research results confirm that political connection is a vital influencing mechanism between debt restructuring and enterprise investment. As far as the 
impact of political intervention on business activities is concerned, on the one hand, intervention can correct the blindness of enterprises as independent individuals in the market economy and play a positive role of "helping hand." On the other hand, political intervention will distort enterprises' decision-making aiming at maximizing shareholder value and achieve social stability and sustainable development at the expense of enterprises' own interests. At the same time, managers in politically connected enterprises usually have the motivation to pursue outstanding performance to achieve promotion. The negative effects of "grabbing hand" are reinforced by strong connections. If the enterprise is in financial distress and actively renegotiates to restructure debt, the debtor usually has a strong incentive to increase supervision over the restructuring enterprise to avoid a new round of renegotiation. The results show that the positive effect of political connection and the supervision effect dominates for the enterprises with weak political connection. However, as the strength of political connection increases, the negative effect of political connection holds.

By researching the influence mechanism of political connections on the link between debt restructuring and investment, we put forward the following recommendations and policy implications to encourage debt restructuring enterprises to pay attention to the impact of political connections and improve the sustainability of distressed enterprises in emerging markets. Firstly, compared with nonpolitical connection enterprises, the investment behaviour of debt restructuring enterprises with political ties has been effectively improved, which indicates that maintaining certain political connection is beneficial for debt restructuring enterprises to improve investment efficiency and get out of trouble. Therefore, it is necessary for enterprises to seek and maintain political ties while pursuing their own economic interests. Secondly, we emphasize the importance of strength of political connection in the investment behaviour and sustainable development of debt restructuring enterprises. When enterprises are in the situation of strong political connection, debt restructuring has a significant negative impact on enterprise investment. Therefore, we encourage the government in the region with assessment of strong political intervention to appropriately reduce the adverse intervention on the distressed debt restructuring enterprises within its jurisdiction and avoid the negative effect of "grabbing hand" of intervention so that enterprises' decision-making can return to the goal of maximizing shareholder value, get out of the predicament as soon as possible, and achieve sustainable development.

\section{Data Availability}

The data used in this study will be made available on request (jjl_sd@163.com).

\section{Conflicts of Interest}

The authors declare that there are no conflicts of interest to this paper.

\section{Acknowledgments}

This work was supported by the Postgraduate Students Innovation Foundation of Shanghai University of Finance and Economics (2017110311).

\section{References}

[1] J.-C. Huang and C.-S. Huang, "The effects of bank relationships on firm private debt restructuring: evidence from an emerging market," Research in International Business and Finance, vol. 25, no. 1, pp. 113-125, 2011.

[2] J. Jiang, B. Liu, and J. Yang, "The impact of debt restructuring on firm investment: evidence from China," Economic Modelling, vol. 81, pp. 325-337, 2019.

[3] K. Inoue, H. K. Kato, and M. Bremer, "Corporate restructuring in Japan: who monitors the monitor?" Journal of Banking \& Finance, vol. 32, no. 12, pp. 2628-2635, 2008.

[4] N. M. Saleh and K. Ahmed, "Earnings management of distressed firms during debt renegotiation," Accounting and Business Research, vol. 35, no. 1, pp. 69-86, 2005.

[5] S. C. Gilson, K. John, and L. H. P. Lang, "Troubled debt restructurings," Journal of Financial Economics, vol. 27, no. 2, pp. 315-353, 1990.

[6] P. Jostarndt and Z. Sautner, "Out-of-Court restructuring versus formal bankruptcy in a non-interventionist bankruptcy setting*." Review of Finance, vol. 14, no. 4, pp. 623-668, 2010.

[7] J.-C. Huang, C.-S. Huang, and C.-F. You, "Bank relationships and the likelihood of filing for reorganization," International Review of Economics \& Finance, vol. 35, pp. 278-291, 2015.

[8] C. Demiroglu and C. James, "Bank loans and troubled debt restructurings," Journal of Finanancial Economics, vol. 118, no. 1, pp. 192-210, 2014.

[9] M. Nishihara and T. Shibata, "Asset sale, debt restructuring, and liquidation," Journal of Economic Dynamics and Control, vol. 67, pp. 73-92, 2016.

[10] G. Micucci and P. Rossi, "Debt restructuring and the role of banks' organizational structure and lending technologies," Journal of Financial Services Research, vol. 51, no. 3, pp. 1-23, 2017.

[11] A. F. Forgione and C. Migliardo, "An empirical analysis of the impact of trade credit on bank debt restructuring," Economia Politica, vol. 36, no. 2, pp. 415-438, 2019.

[12] M. H. Aksu, The Effect of Size, Book-to-Market Ratio, and Prior Distress Information on the Excess Returns to Debt Restructuring Firms, Koc University, Istanbul, Turkey, 2001.

[13] G. Pawlina, "Underinvestment, capital structure and strategic debt restructuring," Journal of Corporate Finance, vol. 16, no. 5, pp. 679-702, 2010.

[14] T. Shibata and M. Nishihara, "Investment-based financing constraints and debt renegotiation," Journal of Banking \& Finance, vol. 51, pp. 79-92, 2015.

[15] T. Sung and D. Kim, "How chaebol restructuring after the 1997 crisis has affected corporate decision and performance in Korea: debt financing, ownership structure, and investment," China Economic Journal, vol. 10, no. 2, pp. 147-161, 2017.

[16] F. Allen, J. Qian, and M. Qian, "Law, finance, and economic growth in China," Journal of Financial Economics, vol. 77, no. 1, pp. 57-116, 2005.

[17] Q. He, X. Li, and W. Zhu, "Political connection and the walking dead: evidence from China's privately owned firms," International Review of Economics \& Finance, 2018, In press.

[18] C. R. Chen, Y. Li, D. Luo, and T. Zhang, "Helping hands or grabbing hands? An analysis of political connections and firm value," Journal of Banking \& Finance, vol. 80, pp. 71-89, 2017. 
[19] X. Wang, G. Fan, and Z. Hu, Marketization Index of China's Provinces: NERI Report 2018, Social Sciences Academic Press, Beijing, China, 2019.

[20] S. Chen, Z. Sun, S. Tang, and D. Wu, "Government intervention and investment efficiency: evidence from China," Journal of Corporate Finance, vol. 17, no. 2, pp. 259-271, 2011.

[21] L. Deng, P. Jiang, S. Li, and M. Liao, "Government intervention and firm investment," Journal of Corporate Finance, 2017, In press.

[22] W.-Y. Wong and C.-W. Hooy, "Do types of political connection affect firm performance differently?" Pacific-Basin Finance Journal, vol. 51, pp. 297-317, 2018.

[23] K. S. Chan, V. Q. T. Dang, and I. K. M. Yan, "Effects of financial liberalisation and political connection on listed Chinese firms' financing constraints," The World Economy, vol. 35, no. 4, pp. 483-499, 2012.

[24] S. Richardson, "Over-investment of free cash flow," Review of Accounting Studies, vol. 11, no. 2-3, pp. 159-189, 2006.

[25] A. Guariglia and J. Yang, "A balancing act: managing financial constraints and agency costs to minimize investment inefficiency in the Chinese market," Journal of Corporate Finance, vol. 36, pp. 111-130, 2016.

[26] X. Wei, C. Wang, and Y. Guo, "Does quasi-mandatory dividend rule restrain overinvestment?" International Review of Economics \& Finance, vol. 63, pp. 4-23, 2019.

[27] M. Cheng, D. Dhaliwal, and Y. Zhang, "Does investment efficiency improve after the disclosure of material weaknesses in internal control over financial reporting?" Journal of Accounting and Economics, vol. 56, no. 1, pp. 1-18, 2013.

[28] D. W. Hosmer, S. Lemeshow, and R. X. Sturdivant, Applied Logistic Regression, Vol. 398, John Wiley \& Sons, Hoboken, NJ, USA, 2013.

[29] G. Gorton and J. Kahn, "The design of bank loan contracts," Review of Financial Studies, vol. 13, no. 2, pp. 331-364, 2000. 